\title{
The synthetic peptide, His-Phe-Tyr-Leu-Pro-Met, is a chemoattractant for Jukat $T$ cells
}

\author{
Youndong Kim ${ }^{1}$, Yoe-Sik Bae ${ }^{1}$, Jun Chul Park ${ }^{1}$, \\ Pann-Ghill Suh ${ }^{1}$ and Sung Ho Ryu ${ }^{1,2}$ \\ ${ }^{1}$ Division of Molecular and Life Sciences, Pohang University of Science \\ and Technology, Pohang 790-784, Korea \\ ${ }^{2}$ Corresponding author: Tel, +82-54-279-2292; \\ Fax, +82-54-279-2199; E-mail, sungho@postech.ac.kr
}

Accepted 3 December 2001

Abbreviation: PTX, pertussis toxin; GPCR, G-protein-coupled receptor;

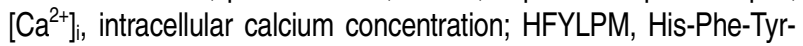
Leu-Pro-Met-CONH${ }_{2}$; PLC, phospholipase C; SDF-1, stromal cellderived factor-1; PI3K, phosphatidylinositol-3-kinase; ERK, extracellular signal-regulated protein kinase

\begin{abstract}
His-Phe-Tyr-Leu-Pro-Met (HFYLPM) is a synthetic peptide that stimulates Jurkat $T$ cells resulting in intracellular calcium $\left(\left[\mathrm{Ca}^{2+}\right]_{\mathrm{i}}\right)$ increase in a pertussis toxin (PTX)-sensitive manner. We have examined the physiological role of the peptide in $\mathrm{T}$ cell activity by comparative investigation of intracellular signaling pathways accompanied with HFYLPM-induced T cell chemotaxis with a well-known chemokine, stromal cell-derived factor-1 (SDF-1)-induced signalings. Wortmannin and genistein inhibited both of HFYLPMand SDF-1-induced Jurkat $T$ cell chemotaxis indicating that phosphoinositide-3-kinase and tyrosine kinase activity were required for the processes. However, U-73122 and BAPTAAM preferentially blocked HFYLPMbut not SDF-1-induced T cell chemotaxis. It indicates that phospholipase $\mathrm{C} /$ calcium signaling is necessary for only chemotaxis by HFYLPM. One of the well-known cellular molecules involving chemotaxis, extracellular signal-regulated protein kinase (ERK), was activated by SDF-1 but not by HFYLPM ruling out a possible role of ERK on the peptide-mediated chemotaxis. These results indicate that the synthetic peptide, HFYLPM, stimulates $T$ cell chemotaxis showing unique signaling and provide a useful tool for the study of $\mathrm{T}$ cell activation mechanism.
\end{abstract}

Keywords: chemotaxis, peptide, G-protein coupled receptor

\section{Introduction}

$\mathrm{T}$ cells have a central role in the regulation of immune responses in host immunity (Goetzl et al. 1992; Lee et al. 1999). For the proper role, T cell activity can be modulated by various extracellular stimuli such as processed peptides on major histocompatibility complex molecules of antigen-presenting cells (Zoller 1988; Ha-Lee et al. 2000). Among these extracellular stimuli, chemoattractants including several chemokines that regulate $\mathrm{T}$ cell functions have been receiving attention for a long time. Most of $T$ cell chemoattractants stimulate the cells via activation of pertussis toxin (PTX)-sensitive G-protein-coupled receptor (GPCR) (Tenscher et al. 1996). Binding of chemoattractants to their specific receptors induce intracellular calcium $\left(\left[\mathrm{Ca}^{2+}\right]_{\mathrm{i}}\right)$ increase, cytoskeletal rearrangement, receptor induction, and the production of bioactive lipids (Castro et al. 1996; Kowalska et al. 2000; Wang et al. 2000; Ragno et al. 2001). On the critical role of chemoattractants in $\mathrm{T}$ cell function, each chemoattractant modulates chemotactic migration of the cells (Gillitzer 2001). While understanding of the biological role of chemoattractants has increased substantially in recent years, relatively little is known about the signaling pathways that mediate chemotactic migration of $\mathrm{T}$ cells. Keeping in mind the important role of chemoattractants for $T$ cell function, the identification of new chemoattractants and the characterization of their action mechanism are essentially needed.

We previously isolated a peptide, His-Phe-Tyr-LeuPro-Met-CONH $\mathrm{H}_{2}$ (HFYLPM), from a peptide library and identified as a synthetic peptide that could stimulate superoxide generation in human monocytes (Bae et al. 2001). The peptide induced the intracellular calcium mobilization via activation of phosphoinositide-specific phospholipase C (PLC) in monocytes (Bae et al. 2001). It also exhibits cell type specificity affecting in several hematopoietic cells including Jurkat $\mathrm{T}$ cells (Bae et al. 2001). The peptide does not have any effect on nonhematopoietic cells such as fibroblasts and neuronal cells (Bae et al. 2001). However, the physiological role of HFYLPM on T cell activity is not examined until now. Since the peptide induced chemotactic migration of monocytes, in this study we investigated a possible role of HFYLPM as a $\mathrm{T}$ cell chemoattractant. We also examined the signaling pathway of the peptide leading to chemotaxis of Jurkat $\mathrm{T}$ cells.

\section{Materials and Methods}

\section{Materials}

The peptide was synthesized, purified, and prepared in the Peptide Library Support Facility at Pohang University of 
Science and Technology as described previously (Beak et al. 1996; Seo et al. 1997). RPMl 1640 was purchased from Life Technologies (Grand Island, NY). Dialyzed fetal bovine serum and supplemented bovine calf serum were purchased from HyClone (Logan, UT). Fura-2/pentaacetoxymethyl ester (fura-2/AM) and 1,2bis(2-aminophenoxy) ethane-N,N,N,N-tetraacetoxymethyl ester (BAPTAAM) were purchased from Molecular Probes (Eugene, OR). Myo$\left[2-{ }^{3} \mathrm{H}\right]$ inositol and the ECL kit were purchased from Amersham Corp. (Bucks, UK). Cell Titer 96 AQueous solution was purchased from Promega (Southampton, UK).

\section{Cell culture}

The Jurkat T lymphoma cells were maintained in RPMI 1640 medium supplemented with $10 \%$ fetal bovine serum. Cells were maintained at densities of $2 \times 10^{5}$ cells $/ \mathrm{ml}$ at $37^{\circ} \mathrm{C}$ in a humidified incubator supplied with $95 \%$ air and $5 \% \mathrm{CO}_{2}$.

\section{Chemotaxis assay}

Chemotaxis assays were performed using multiwell chambers (Neuroprobe Inc. Gaithersburg, MD). Briefly, Jurkat T cells were suspended in RPMl at densities of $3 \times 10^{6}$ cells $/ \mathrm{ml}$, and $1.5 \times 10^{5}$ of cells were placed onto the upper well of chamber that is separated by $10 \mu \mathrm{m}$ pore polyhydrocarbon filter from peptide, or SDF-1 containing lower well. After incubation for $3 \mathrm{~h}$ at $37^{\circ} \mathrm{C}$, nonmigrated cells were discarded, and cells that migrated across the filter were centrifuged and resuspended in $100 \mu \mathrm{l}$ of RPMI, then added $20 \mu \mathrm{l}$ of Cell Titer $96 \mathrm{AQ}_{\text {ueous }}$ solution. After $2 \mathrm{~h}$, quantification was performed by checking absorbance at $490 \mathrm{~nm}$.

\section{Measurement of $\left[\mathrm{Ca}^{2+}\right]_{i}$}

The level of $\left[\mathrm{Ca}^{2+}\right]_{i}$ was determined by Grynkiewiczs method using fura-2/AM (Grynkiewicz et al. 1985). Briefly, Cells were incubated with $3 \mu \mathrm{M}$ of fura-2/AM at $37^{\circ} \mathrm{C}$ for 50 min in fresh serum free RPMI 1640 medium under continuous stirring. Cells were resuspended with serum free medium and $2 \times 10^{6}$ cells were aliquoted for each assay in calcium free Lockes solution $(154 \mathrm{mM} \mathrm{NaCl}$, $5.6 \mathrm{mM} \mathrm{KCl}, 1.2 \mathrm{mM} \mathrm{MgCl}, 5 \mathrm{mM}$ HEPES, pH 7.3, $10 \mathrm{mM}$ glucose, and $0.2 \mathrm{mM}$ EGTA). The fluorescence changes at the dual excitation wavelength of $340 \mathrm{~nm}$ and $380 \mathrm{~nm}$ and the emission wavelength of $500 \mathrm{~nm}$ were measured.

\section{Measurement of tyrosine phosphorylation and ERK activation}

Jurkat $\mathrm{T}$ cells were resuspended to $1 \times 10^{7}$ cells $/ \mathrm{ml}$ in serum-free RPMI 1640 and then stimulated for various length of time with $10 \mu \mathrm{M}$ peptide at $37^{\circ} \mathrm{C}$. The reaction was stopped by discarding the reaction medium and adding $200 \mu$ l of lysis buffer (20 mM Hepes, $\mathrm{pH} 7.2,10 \%$ glycerol, $150 \mathrm{mM} \mathrm{NaCl}, 1 \%$ Triton X-100, $50 \mathrm{mM} \mathrm{NaF}, 1 \mathrm{mM}$ $\mathrm{Na}_{3} \mathrm{VO}_{4}, 10 \mu \mathrm{g} / \mathrm{ml}$ of leupeptin, and $1 \mathrm{mM}$ phenylmethylsulfunyl fluoride). Proteins were extracted by setting the samples on ice for $60 \mathrm{~min}$. The extracted proteins were harvested by centrifugation $\left(15,000 \mathrm{~g}, 15 \mathrm{~min}, 4^{\circ} \mathrm{C}\right)$ and used for immunoblot analysis.

\section{Immunoblot analysis}

Prepared samples were separated on $8 \%$ sodium dodecyl sulfate-polyacrylamide gel electrophoresis (SDS-PAGE) and transferred onto nitrocellulose membrane. After blocking the membrane with 5\% skimmed milk in TBST (10 mM Tris- $\mathrm{HCl}, \mathrm{pH} 8.0,150 \mathrm{mM} \mathrm{NaCl}$, and $0.05 \%$ Tween 20), the membranes were incubated for $4 \mathrm{~h}$ with $1 \mu \mathrm{g} / \mathrm{ml}$ of anti-phosphotyrosine antibodies, antiphosphoERK antibodies, or anti-ERK antibodies. Detection was performed with a peroxidase-conjugated anti-mouse (or rabbit or goat) IgG secondary antibody and an enhanced chemiluminescence system (Amersham, UK).

\section{Results}

\section{HFYLPM stimulates $\left[\mathrm{Ca}^{2+}\right]_{i}$ increase in a PTX sensitive} manner in Jurkat $T$ cells

When stimulated with various concentrations of HFYLPM, Jurkat $T$ cells responded with a concentration-dependent increase of intracellular calcium (Figure 1A). The peptide evoked a rise in the $\left[\mathrm{Ca}^{2+}\right]_{i}$ at micromolar concentrations, and the maximal response was observed around $20 \mu \mathrm{M}$ peptide concentration. As a negative control we checked the effect of a scrambled sequence peptide, LFMYHP, for the active peptide on $\left[\mathrm{Ca}^{2+}\right]_{i}$ increase in Jurkat T cells, and confirmed that the scrambled sequence peptide could not induce any significant intracellular calcium increase at concentrations up to $20 \mu \mathrm{M}$ (Figure 1A). To address the effect of PTX-sensitive G-protein for the HFYLPM-induced $\left[\mathrm{Ca}^{2+}\right]$ increase, we introduced PTX. Pretreatment of the Jurkat T cells with $100 \mathrm{ng} / \mathrm{ml}$ of PTX for $24 \mathrm{~h}$, almost completely blocked the peptide-induced $\left[\mathrm{Ca}^{2+}\right]_{i}$ increase (Figure 1B). The result indicates that the synthetic peptide, HFYLPM, stimulates Jurkat $\mathrm{T}$ cells leading to $\left[\mathrm{Ca}^{2+}\right]_{i}$ increase, and PTX-sensitive G-protein is involved in the process.

\section{HFYLPM induces T cell chemotaxis in a PTX-sensitive manner}

Our previous report (Bae et al. 2001) demonstrating that HFYLPM acts as a chemoattractant for human monocytes led us to investigate a possible role of the peptide as a T cell chemoattractant. To assess the effect of HFYLPM on $\mathrm{T}$ cell migration, chemotaxis assays were performed in Jurkat $T$ cells by using a modified Boyden chamber analysis described before (Zhou et al. 1995). The peptide induced chemotactic migration of Jurkat $\mathrm{T}$ cell within $10 \mathrm{nM}-10 \mu \mathrm{M}$ showing a bell shaped concentrationresponsive curve (Figure $2 \mathrm{~A}$ ). The scrambled sequence 


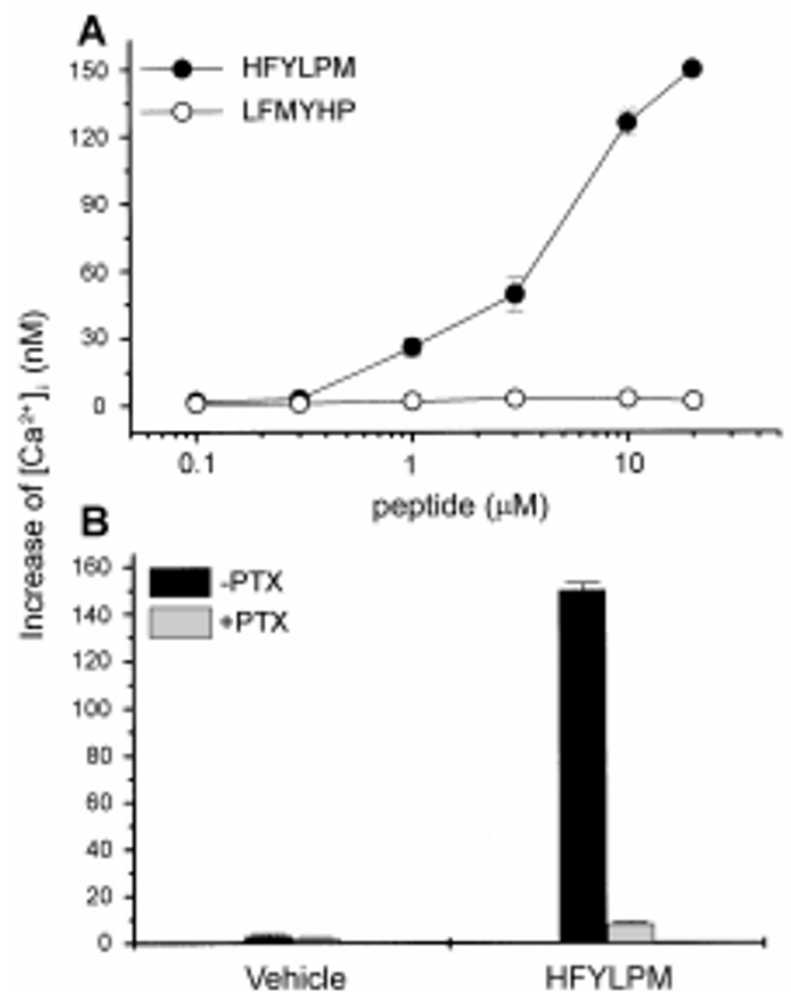

Figure 1. HFYLPM stimulates $\left[\mathrm{Ca}^{2+}\right]$ increase of Jurkat $\mathrm{T}$ cell in a PTXsensitive manner. $\left[\mathrm{Ca}^{2+}\right]_{i}$ was determined fluorometrically using fura-2/AM, as described in Materials and Methods. Fura-2 loaded cells were challenged with various concentrations of HFYLPM or LFMYHP (A). To check the effect of PTX, cells were incubated in the absence or presence of $100 \mathrm{ng} / \mathrm{ml}$ of PTX for $24 \mathrm{~h}$ prior to $\left[\mathrm{Ca}^{2+}\right]_{i}$ determination. Data are presented as mean \pm SE from three independent experiments performed in duplicate.

peptide (LFMYHP) for HFYLPM did not affect on Jurkat $\mathrm{T}$ cell migration within $1 \mathrm{nM}-10 \mu \mathrm{M}$ concentration (Figure 2A). A well-known chemoattractant for Jurkat T cells, stromal cell-derived factor-1 (SDF-1) also induced chemotactic migration in the cells (Figure 2A). The chemotactic activity mediated by peptide at a concentration of $1 \mu \mathrm{M}$ is about $60 \%$ of that mediated by SDF- 1 at a concentration of $10 \mathrm{nM}$ in Jurkat $\mathrm{T}$ cells. Recently, it has been reported that chemokine receptors are coupled to the PTX-sensitive heterotrimeric G proteins (Tenscher et al. 1996). We checked the effect of PTX on HFYLPM-induced chemotaxis in Jurkat $T$ cells. As shown in Figure 2B, HFYLPM-induced chemtaxis was almost completely inhibited by pretreatment of PTX. In the case of SDF-1, PTX pretreatment also caused almost complete inhibition of the chemotactic migration (Figure $2 \mathrm{~B}$ ). The result implicates that HFYLPM-induced chemotaxis has signaling pathways that start from PTX-sensitive $G$ proteincoupled receptor, as SDF-1-induced one.

\section{PLC-mediated calcium increase is required for HFYLPM-induced chemotaxis}

Generally, chemoattractants have been reported to
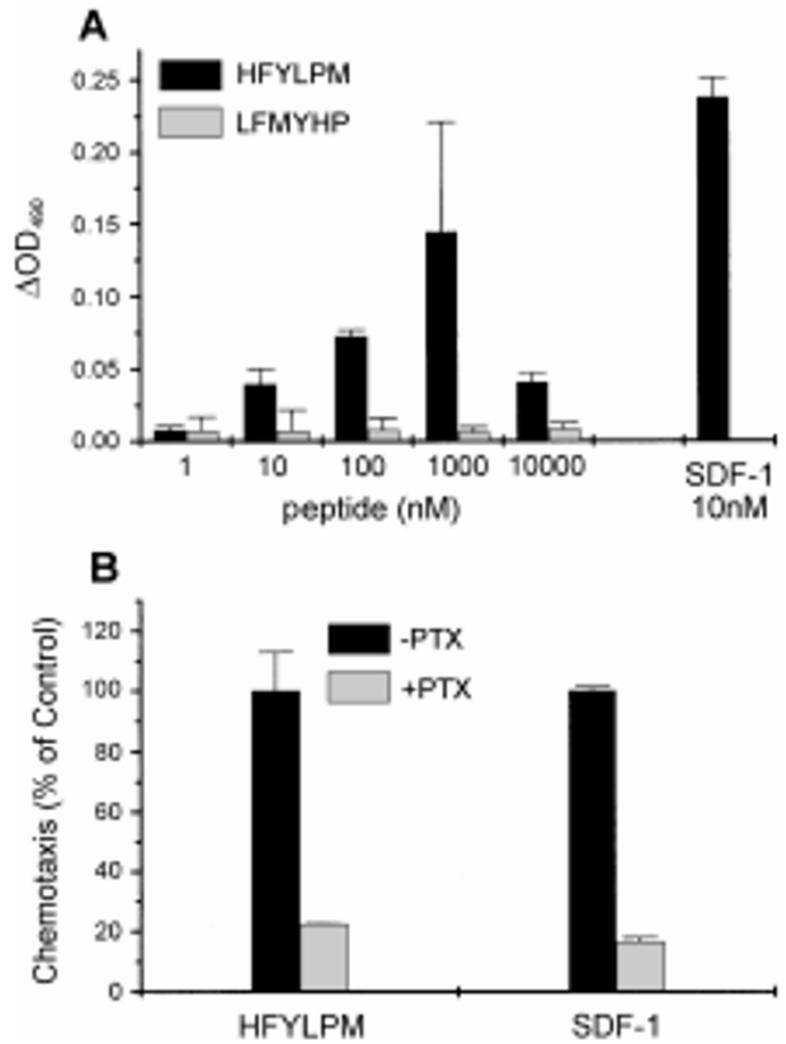

Figure 2. HFYLPM induces chemotaxis of Jurkat $T$ cell. Assays were performed using Boyden chamber. Cells ( $3 \times 10^{6} \mathrm{cells} / \mathrm{ml}$ of serum-free RPMI) were added to the upper wells of a 96-well chemotaxis chamber and migration across the polycarbonate membrane with $10 \mu \mathrm{m}$ pore size was assessed after $3 \mathrm{~h}$-incubation at $37^{\circ} \mathrm{C}$. Various concentrations of HFYLPM, LFMYHP, or $10 \mathrm{nM}$ SDF-1 were used (A). To check the effect of PTX on the peptide-induced chemotaxis, cells were pretreated with $100 \mathrm{ng} / \mathrm{ml}$ of PTX for $24 \mathrm{~h}$ prior to the assay (B). The migrated cells were determined by using One-solution cell titer kit. Data are presented as mean \pm SE of three independent experiments each performed in duplicate.

induce PI hydrolysis resulting from PLC activation in leukocytes (Wu et al. 1993). We also observed that HFYLPM stimulated $\left[\mathrm{Ca}^{2+}\right]_{i}$ increase in Jurkat $\mathrm{T}$ cells (Figure $1 \mathrm{~A}$ ). The peptide-induced $\left[\mathrm{Ca}^{2+}\right]_{\mathrm{i}}$ increase was sensitive to the pretreatment of the cells with U-73122, a specific PLC inhibitor (data not shown), indicating that HFYLPM-induced $\left[\mathrm{Ca}^{2+}\right]_{i}$ increase was derived from PLC activation. The role of PLC activity in HFYLPMinduced chemotaxis was also examined by using a specific PLC inhibitor, U-73122. As shown in Figure 3A, HFYLPM-induced chemotaxis was partially ( $30 \%$ of total) blocked by $\mathrm{U}-73122$ but not by $\mathrm{U}-73343$, an inactive analogue for U-73122. SDF-1-induced chemotaxis, however, was not affected by U-73122 pretreatment (Figure $3 A)$. We also checked the role of intracellular calcium increase on HFYLPM-induced chemotaxis by using an intracellular calcium chelator, BAPTA/AM. Pretreatment of the cells with $1 \mu \mathrm{g} / \mathrm{ml}$ of BAPTA/AM for 30 min prior to the chemotaxis assay attenuated HFYLPM-induced chemotaxis without affecting on SDF-1-induced one (Figure 


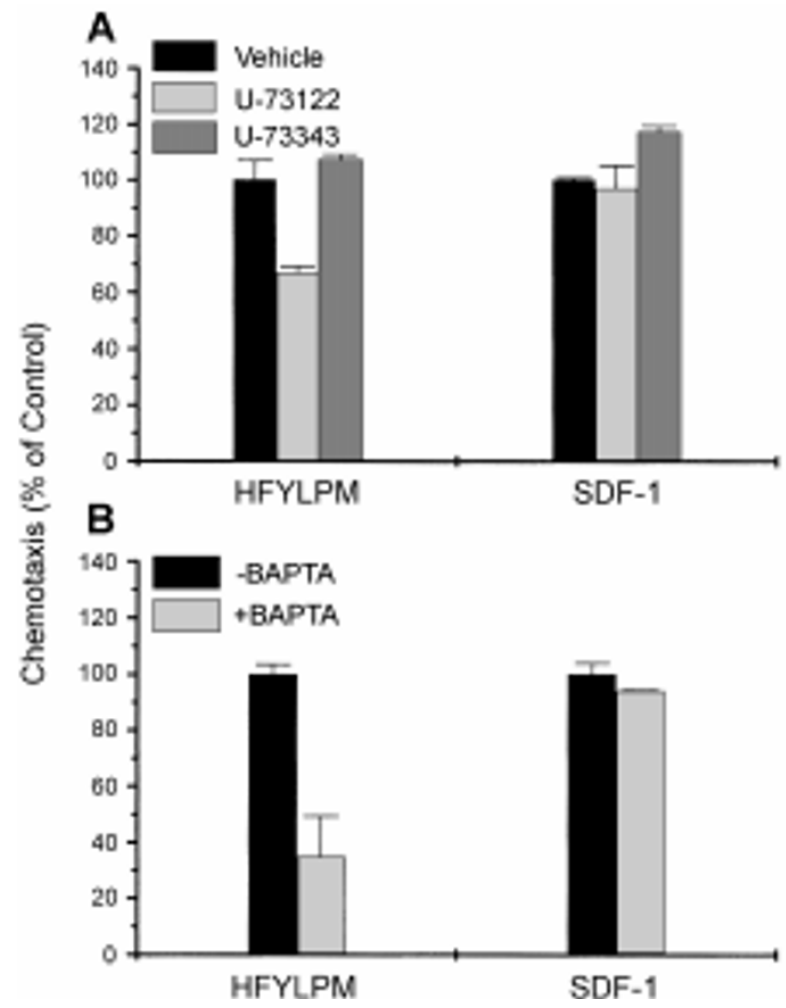

Figure 3. HFYLPM-induced T cell chemotaxis is PLC/calcium signalingdependent. Jurkat T cells were treated with $2 \mu \mathrm{M}$ of U-73122, $2 \mu \mathrm{M}$ of $\mathrm{U}$ 73343 (A) or $1 \mu \mathrm{g} / \mathrm{ml}$ of BAPTA/AM (B) for $15 \mathrm{~min}$ or $30 \mathrm{~min}$, respectively. Then the cells were used for chemotaxis assay with $1 \mu \mathrm{M}$ HFYLPM or $10 \mathrm{nM}$ SDF-1 for $3 \mathrm{~h}$. Data are presented as mean \pm SE from three independent experiments performed in duplicate.

3B). These results indicate that HFYLPM- but not SDF1-induced chemotaxis requires PLC and calcium signaling.

\section{HFYLPM-induced chemotaxis is phosphatidylinositol- 3-kinase-dependent}

It has been reported that phosphatidylinositol 3-kinase (PI3K) takes major role in leukocytic chemotaxis (Stoyaniv et al. 1995; Stephen et al. 1997). Recently, it has been also demonstrated that PI3K is important in T cell chemotaxis, by several chemoattractants including SDF-1 (Sotsios et al. 1999). In this study, we checked whether HFYLPM-induced chemotaxis is PI3K dependent or not by using a PI3K inhibitor, wortmannin. As shown in Figure 4, pretreatment of Jurkat $T$ cells with wortmannin caused around $40 \%$ of inhibition in both of HFYLPM- and SDF-1-induced chemotaxis. This result indicates that PI3K is an important mediator for both HFYLPM and SDF-1-induced T cell chemotaxis.

\section{HFYLPM-induced chemotaxis is tyrosine kinase activity- dependent}

Since many chemokines stimulate tyrosine kinase activity in T cells (Entschladen et al. 2000), we also checked the effect of HFYLPM on tyrosine phosphory-

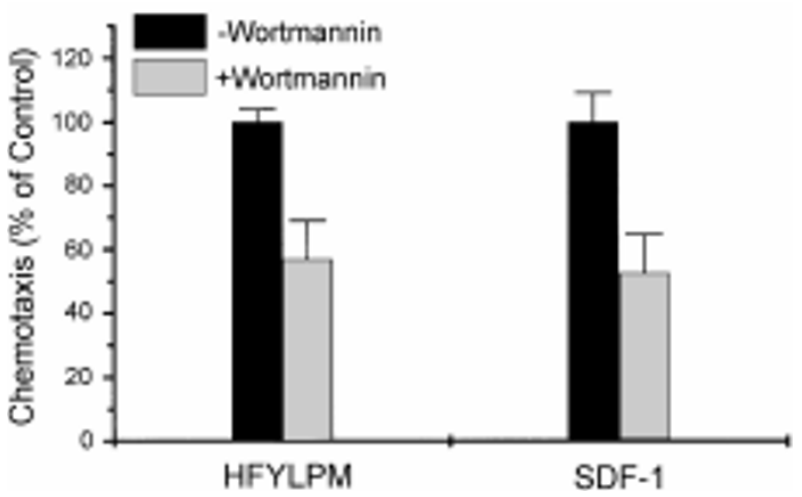

Figure 4. HFYLPM-induced chemotaxis requires PI3K activity. Cells were treated with wortmannin $(50 \mu \mathrm{g} / \mathrm{ml})$ or vehicle alone for $15 \mathrm{~min}$. The cells were used for chemotaxis assay with $1 \mu \mathrm{M} \mathrm{HFYLPM}$ or $10 \mathrm{nM}$ SDF-1 for $3 \mathrm{~h}$. Data are presented as mean \pm SE from three independent experiments performed in duplicate.

lation of cellular proteins. As shown in Figure 5A, HFYLPM enhanced tyrosine phosphorylation levels of several cellular proteins such as $120 \mathrm{kD}, 85 \mathrm{kD}$, and $60 \mathrm{kD}$ proteins. SDF-1 also caused tyrosine phosphorylation of several cellular proteins showing similar pattern with that of HFYLPM-induced (Figure 5A). Tyrosine phosphorylation events induced by HFYLPM or SDF-1 were abolished by pretreatment of the cells with a tyrosine kinase inhibitor, genistein (data not shown). It was reported that SDF-1-induced T cell chemotaxis was tyrosine kinase activity-dependent (Entschladen et al. 2000). We checked the role of tyrosine kinase activity on HFYLPM-induced chemotaxis using genistein. As shown in Figure 5B, pretreatment of Jurkat $T$ cells with $100 \mu \mathrm{M}$ of genistein caused around $60 \%$ of inhibition of HFYLPM-induced chemotaxis. SDF-1-induced chemotaxis was also sensitive to the genistein (Figure $5 \mathrm{~B}$ ). These results indicate that both HFYLPM- and SDF-1-induced chemotaxis are tyosine kinase activity-dependent.

\section{SDF-1 but not HFYLPM stimulates ERK activity}

Many reports showed that chemoattractants stimulate ERK activity and this activity is required for the leukocyte chemotaxis event (Dutt et al. 1998; Sotsios et al. 1999). We checked the effect of HFYLPM on ERK activity by monitoring phosphorylation level of ERK with antiphospho-specific ERK antibody. Stimulation of Jurkat T cells with $10 \mathrm{nM}$ SDF-1 caused time-dependent ERK activation within 0.5-10 min after treatment (Figure 6). However, $10 \mu \mathrm{M}$ HFYLPM could not stimulate ERK activity in Jurkat $T$ cells (Figure 6). The result suggests that two different chemoattractants, SDF-1 and HFYLPM, mediate different signaling in view of ERK activation in Jurkat T cells.

\section{Discussion}

In this study, we demonstrated that the synthetic pep- 

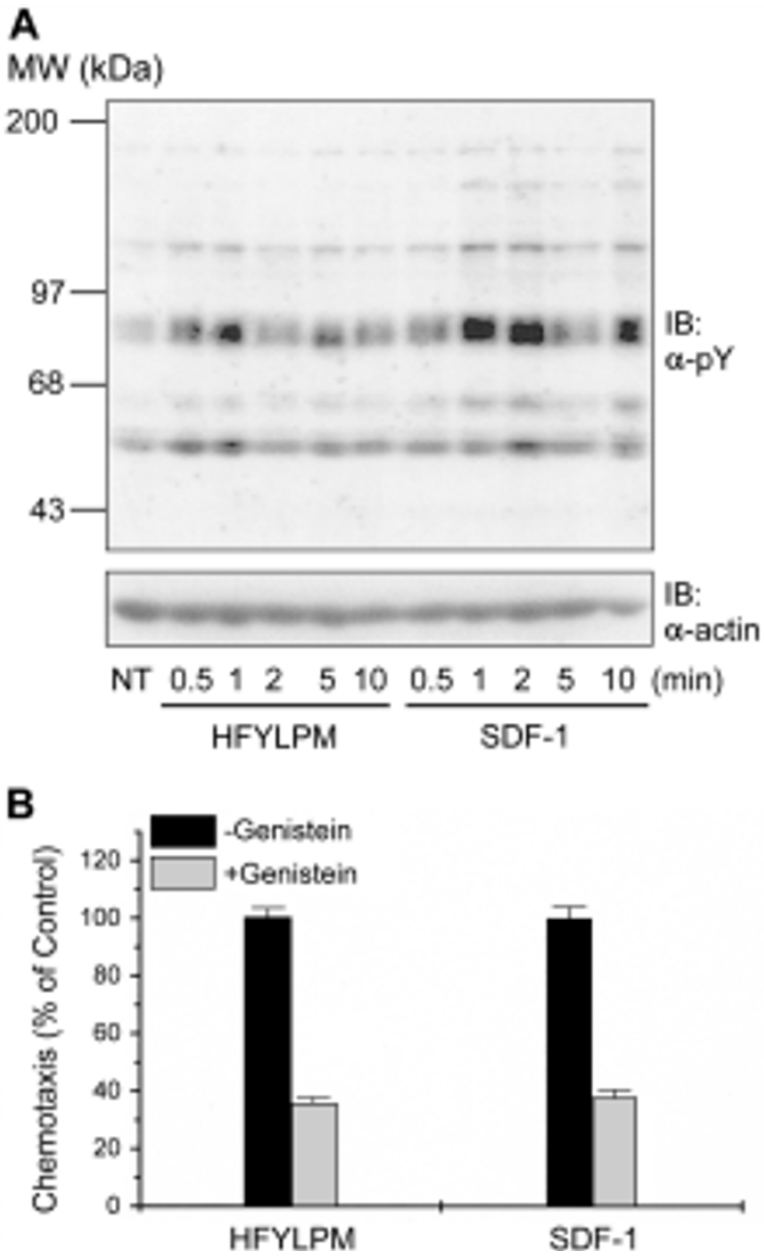

Figure 5. HFYLPM induces tyrosine kinase activity and HFYLPM-induced chemotaxis is dependent on tyrosine kinase activity. Cells were challenged with $1 \mu \mathrm{M}$ HFYLPM or $10 \mathrm{nM}$ SDF-1 for various lengths of period. The samples were subjected to SDS-PAGE as described under Materials and Methods. Immunoblot assay was performed by using anti-phosphotyrosine antibody (A). Cells were treated with $100 \mu \mathrm{M}$ genistein or vehicle only for 15 min prior to chemotaxis assay with $1 \mu \mathrm{M}$ HFYLPM or $10 \mathrm{nM}$ SDF-1. Data are presented as mean \pm SE from three independent experiments performed in duplicate.

tide, HFYLPM, induced Jurkat $\mathrm{T}$ cell chemotaxis. We also compared the signaling of HFYLPM-induced chemotaxis with that of SDF-1, a well-known chemokine. HFYLPM-induced chemotaxis has some overlapped and some distinct signal pathways with SDF-1-induced one. HFYLPM and SDF-1 share the signaling via PTXsensitive G-protein, PI3K, and tyrosine kinase (Figure $2 \mathrm{~B}, 4$, and $5 \mathrm{~B}$ ). The peptide has a distinct signaling pathway for chemotaxis with SDF-1 in PLC-mediated calcium and ERK-mediated signaling.

Several reports demonstrated that chemoattactants including SDF-1 induced PLC activation resulting in $\left[\mathrm{Ca}^{2+}\right]_{\mathrm{i}}$ increase in $\mathrm{T}$ cell (Hesselgesser et al. 1998). However, the role of chemoattractant-induced PLC/ calcium signaling on $\mathrm{T}$ cell chemotaxis was not clearly

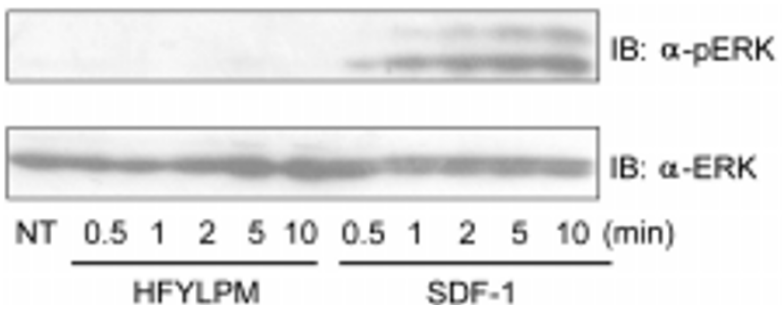

Figure 6. SDF-1 but not HFYLPM stimulates ERK activity. Cells were challenged with $10 \mu \mathrm{M}$ HFYLPM or $10 \mathrm{nM}$ SDF-1 for various lengths of period as indicated. The levels of ERK phosphorylation were measured with immunoblot analysis by using anti-phospho-ERK antibody. To confirm that same amounts of proteins were used for the experiment, immunoblot analysis with anti-ERK antibody was performed.

understood until now. In this study, we observed HFYLPM stimulated $\left[\mathrm{Ca}^{2+}\right]_{i}$ increase via PLC activation (Figure $1 \mathrm{~A}$ and data not shown). Since HFYLPMinduced Jurkat cell migration was sensitive to U-73122 and BAPTA/AM (Figure 2A and 2B), PLC activity as well as $\left[\mathrm{Ca}^{2+}\right]_{i}$ increase may be important in the peptideinduced chemotaxis. Unlike to the HFYLPM-induced chemotaxis, SDF-1-induced T cell chemotaxis was not sensitive to $\mathrm{U}-73122$ or BAPTA/AM (Figure $2 \mathrm{~A}$ and $2 \mathrm{~B}$ ). These results suggest that $\mathrm{PLC/calcium}$ signaling might be involved in $\mathrm{T}$ cell chemotaxis showing a ligandspecific manner.

PI3K and ERK have been reported to act important roles in the chemoattractant-mediated signalings as downstream of PTX-sensitive GPCR (Hii et al. 1999; Bonacchi et al. 2001). The two molecules, PI3K and ERK have been reported to play a role in chemotaxis of $\mathrm{T}$ cells (Sotsios et al. 1999). In this study we also observed that PI3K might be involved in the HFYLPMand SDF-1-induced $T$ cell chemotaxis (Figure 4). On ERK activation, we found that SDF-1 promoted ERK phosphorylation as reported before (Yonezawa et al. 2000). The ERK activity is reported to be involved in SDF-1-induced T cell chemotaxis (Hii et al. 1999). However, the synthetic peptide, HFYLPM, could not stimulate ERK activity in Jurkat $T$ cells (Figure 6). Reminding that the two agonists, HFYLPM and SDF-1, induced T cell chemotaxis, it looks like that while both PI3K and ERK activation are necessary for SDF-1mediated chemotaxis, PI3K-dependent but ERK-independent mechanism is activated by HFYLPM-induced chemotaxis in Jurkat $\mathrm{T}$ cell.

Although several chemokines and chemoattractants have been identified, no short peptides modulating $T$ cell chemotaxis have been known until now. In this study, we demonstrated that HFYLPM modulates $\mathrm{T}$ cell activity in terms of chemotaxis and the peptide-induced $\mathrm{T}$ cell signaling has some unique features against wellknown chemokine, SDF-1-induced one. Taken together, the synthetic peptide, HFYLPM, can serve as a useful agonist to characterize $\mathrm{T}$ cell activation mechanism. 


\section{Acknowledgements}

This work was supported in part by grants from the innovative research project of POSCO, and the National Research Laboratory administrated by the Ministry of Science and Technology

\section{References}

Bae YS, Bae HJ, Kim Y, Lee TG, Suh PG, Ryu SH. Identification of novel chemoattractant peptides for human leukocytes. Blood 2001;97:2854-62

Baek SH, Seo JK, Chae CB, Suh PG, Ryu SH. Identification of the peptides that stimulate the phosphoinositide hydrolysis in lymphocyte cell lines from peptide libraries. J Biol Chem 1996;271:8170-75

Bonacchi A, Romagnani P, Romanelli RG, Efsen E, Annunziato F, Lasagni L, Francalanci M, Serio M, Laffi G, Pinzani M, Gentilini P, Marra F. Signal transduction by the chemokine receptor CXCR3: activation of Ras/ERK, Src, and phosphatidylinositol 3-kinase/Akt controls cell migration and proliferation in human vascular pericytes. J Biol Chem 2001;276:9945-54

Castro M, Bjoraker JA, Rohrbach MS, Limper AH. Candida albicans induces the release of inflammatory mediators from human peripheral blood monocytes. Inflammation 1996;20:107-22

Dutt P, Wang JF, Groopman JE. Stromal cell-derived factor-1 alpha and stem cell factor/kit ligand share signaling pathways in hemopoietic progenitors: a potential mechanism for cooperative induction of chemotaxis. J Immunol 1998;161:3652-58

Entschladen F, Gunzer M, Scheuffele CM, Niggemann B, Zanker KS. T lymphocytes and neutrophil granulocytes differ in regulatory signaling and migratory dynamics with regard to spontaneous locomotion and chemotaxis. Cell Immunol 2000; 199:104-14

Gillitzer R. Inflammation in human skin: a model to study chemokine-mediated leukocyte migration in vivo. J Pathol 2001;194:393-94

Goetzl EJ, Sreedharan SP. Mediators of communication and adaptation in the neuroendocrine and immune systems. FASEB J 1992;6:2646-52

Grynkiewicz G, Poenie M, Tsien RY. A new generation of $\mathrm{Ca}^{2+}$ indicators with greatly improved fluorescence properties. J Biol Chem 1985;260:3440-50

Ha-Lee YM, Lee Y, Kim YK, Sohn J. Cross-linking of CD4 induces cytoskeletal association of CD4 and p56 lck. Exp Mol Med 2000;32:18-22

Hesselgesser J, Liang M, Hoxie J, Greenberg M, Brass LF, Orsini MJ, Taub D, Horuk R. Identification and characterization of the CXCR4 chemokine receptor in human $T$ cell lines: ligand binding, biological activity, and HIV-1 infectivity. J Immunol 1998;160:877-83

Hii CS, Stacey K, Moghaddami N, Murray AW, Ferrante A. Role of the extracellular signal-regulated protein kinase cascade in human neutrophil killing of Staphylococcus aureus and Candida albicans and in migration. Infect Immun 1999;67:1297-302

Kowalska MA, Ratajczak MZ, Majka M, Jin J, Kunapuli S, Brass L, Poncz M. Stromal cell-derived factor-1 and macrophagederived chemokine: 2 chemokines that activate platelets. Blood 2000:96:50-57

Lee WH, Lee Y, Kim JR, Chu JA, Lee SY, Jung JO, Kim JS, Kim S, Seo JD, Rhee SS, Park JE. Activation of monocytes, T-lymphocytes and plasma inflammatory markers in angina patients. Exp Mol Med 1999:31:159-64

Ragno S, Romano M, Howell S, Pappin DJ, Jenner PJ, Colston MJ. Changes in gene expression in macrophages infected with Mycobacterium tuberculosis: a combined transcriptomic and proteomic approach. Immunology 2001;104:99-108

Seo JK, Choi SY, Kim Y, Baek SH, Kim KT, Chae CB, Lambeth JD, Suh PG, Ryu SH. A peptide with unique receptor specificity: stimulation of phosphoinositide hydrolysis and induction of superoxide generation in human neutrophils. $J$ Immunol 1997;158:1895-901

Sotsios Y, Whittaker GC, Westwick J, Ward SG. The CXC chemokine stromal cell-derived factor activates a Gi-coupled phosphoinositide 3-kinase in T lymphocytes. J Immunol 1999; 163:5954-63

Stephens LR, Equinoa A, Erdjument-Bromage H, Lui $M$, Cooke F, Coadwell J, Smrcka AS, Thelen M, Cadwallader K, Tempst P, Hawkins PT. The $G$ beta gamma sensitivity of a PI3K is dependent upon a tightly associated adaptor, p101. Cell 1997;89:105-14

Stoyanov B, Volinia S, Hanck T, Rubio I, Loubtchenkov M, Malek D, Stoyanova S, Vanhaesebroeck B, Dhand R, Nurnberg B, Gierschik P, Seedorf K, Hsuan JJ, Waterfield MD, Wetzker R. Cloning and characterization of a $G$ protein-activated human phosphoinositide-3 kinase. Science 1995;269:690-93

Tenscher K, Metzner B, Schopf E, Norgauer J, Czech W. Recombinant human eotaxin induces oxygen radical production, $\mathrm{Ca}(2+)$-mobilization, actin reorganization, and $\mathrm{CD} 11 \mathrm{~b}$ upregulation in human eosinophils via a pertussis toxin-sensitive heterotrimeric guanine nucleotide-binding protein. Blood 1996;88:3195-99

Wang JF, Park IW, Groopman JE. Stromal cell-derived factor1alpha stimulates tyrosine phosphorylation of multiple focal adhesion proteins and induces migration of hematopoietic progenitor cells: roles of phosphoinositide-3 kinase and protein kinase C. Blood 2000;95:2505-13

Wu D, LaRosa GJ, Simon MI. G protein-coupled signal transduction pathways for interleukin-8. Science 1993;261:101-103

Yonezawa A, Hori T, Sakaida H, Uchiyama T. SDF-1 has costimulatory effects on human $\mathrm{T}$ cells: possible involvement of MAPK (ERK2) activation. Microbiol Immunol 2000;44:135-41

Zhou D, Luini W, Bernasconi S, Diomede I, Salmona M, Mantovani A, Sozzani S. Phosphatidic acid and lysophosphatidic acid induce haptotactic migration of human monocytes. J Biol Chem 1995;270:25549-56

Zoller M. IFN-treatment of B16-F1 versus B16-F10: relative impact on non-adaptive and T-cell-mediated immune defense in metastatic spread. Clin Exp Metastasis 1988;6:411-29 